Asian J. Med. Biol. Res. 2020, 6 (3), 431-439; doi: 10.3329/ajmbr.v6i3.49791

\author{
Asian Journal of \\ Medical and Biological Research \\ ISSN 2411-4472 (Print) 2412-5571 (Online) \\ www.ebupress.com/journal/ajmbr
}

\title{
Article \\ Knowledge and attitude of senior staff nurses regarding geriatrics health care in a tertiary public hospital
}

\author{
Md Shohel Mahmud ${ }^{1 *}$, Most Khadija Begum² and Jabin Akhter ${ }^{3}$ \\ ${ }^{1}$ Senior Staff Nurse, Dept. of ICU, Rangpur Medical College Hospital, Rangpur, Bangladesh \\ ${ }^{2}$ Senior Staff Nurse, Dept. of Paediatric, Rangpur Medical College Hospital, Rangpur, Bangladesh \\ ${ }^{3}$ Assitant Professor, Dept. of Microbiology and Mycology, National Institute of Preventive and Social Medicine \\ (NIPSOM), Mohakhali, Dhaka, Bangladesh
}

*Corresponding author: Md Shohel Mahmud, Senior Staff Nurse, Dept. of ICU, Rangpur Medical College Hospital, Rangpur, Bangladesh. Phone: +8801716297355; E-mail: shohel.ssn75@ gmail.com

Received: 22 June 2020/Accepted: 20 July 2020/ Published: 30 September 2020

\begin{abstract}
There is proportionate increase in the health problems along with increase in geriatric population in Bangladesh. Nurses need to be well equipped with knowledge and should also have a positive attitude regarding geriatric care. The current cross sectional study conducted with an aim to assess the knowledge and attitude of senior staff nurses and associated factors regarding geriatrics health care. This cross-sectional study was conducted among 384 nurses working at a tertiary public hospitals in the Rangpur city of Bangladesh from January 2019 to December, 2019. Participants were selected using simple random sampling from the list of staff. The Kogan's attitude questionnaire was used to measure nurses' attitudes toward the elderly. Out of 384 respondents, $36.5 \%$ were of age group 21-30 years, most of female (84.4\%) and married (85.2\%) with maximum Muslim (88.5\%) religious view. About half of the respondents had diploma level education (53.9\%) and having 1-5 years job experience (48.7\%). 64.1\% respondents have monthly income within BDT 2500135000. 35.4\% of the nurses agreed for skill nursing and 36.5\% agreed for challenging and stimulating nursing care, and 54.2\% nurses agree for need highly skilled nursing. Most (97.7\%) of the nurses opined needs special geriatric wards for effective care and 93.8\% requires special training. According to Kogan attitudes scale, 36.2\% nurse had negative attitudes and $63.8 \%$ had positive attitudes regarding geriatric health care. More than one third (38.5\%) of respondents were average knowledge; followed by $32.8 \%$ respondents were good knowledge. There is a statistically significant relationship present between job experience and attitude $\left(\lambda^{2}=26.193, p<0.05\right)$ and job experience and knowledge $\left(\lambda^{2}=15.04, p<0.04\right)$ of nurses. It was concluded that senior staff nurses had average knowledge and positive attitude regarding geriatric care.
\end{abstract}

Keywords: knowledge; attitude; nurse; care; geriatrics

\section{Introduction}

Old age is a period when irretrievable physiological, chronological, spiritual and social changes and losses of roles are experienced and the adaptation of the system to the environment decreases. Elderly individuals often experience more than one health problem and visit health institution usually. The length of the period of old age brings increased need for long-term care (Argaw et al., 2018). The world older population continues to grow rapidly as fertility rates have fallen to very low levels in most world regions and people tend to live longer (Alamri et al., 2017).

Elderly people are increasing in all countries of the World. Globally, an estimated of 605 million people aged 60 years and above (Anil et al., 2006). In Bangladesh perspective according to the National census between 1974 and 2011 the growth of elderly people is gradually increasing. In 1974, the populations between 60-64 years were 1.6 million and in 2011 the numbers were 3.2 million. At the same way aged between 65-69 years population were 735255 and 1998760 in 1974 and 2011 respectively. In the same period of time populations of 
elderly over 70 years were 1.6 million to 1.9 million. Report shows that percentage of elderly people aged between 60-64, 65-69, 70-75 and over 70 years were 37\%, 21\% 20\% and 22\% respectively (Barikdar et al., 2016). Previously the society of Bangladesh took care of the elderly but now the situation is becoming changed due to change of social, psychological and economic standpoint. Moreover, research shows that children of older parents in Bangladesh live in cities for education, employment or living. Again, the older people feel comfortable to live in the rural settings. According to the study by Rahman (2000) $44.3 \%$ people live in poverty and in order to maintain their living expenses as well as family needs, the elderly people got involved in beggary. However, older women especially widows and those who are without sons are facing economic vulnerability and consequence of health problem (Kabir et al., 2005).

Elderly suffer from various types of health problems which may demand long term psychosocial treatment, nursing care and hospitalization. So, the current demographic and health utilization trends strongly indicate a rapidly increasing demand for nurses who are well qualified to care for older adults. There is a growing need for motivated nurses to provide care for older people (Doherty et al., 2011). Various functions of nurses that can contribute to the optimum health and overall wellbeing of the older people include supportive, restorative, educative, life-enhancing and managerial (Kaur et al., 2014).

Several studies investigating the nurse's knowledge and attitudes toward care of older people and their willingness to work with them have been conducted in various countries. The majority of these studies have concluded that most nurses have little knowledge and interest in working with older people (Celik et al., 2010; Oyetunde et al., 2013; Faronbi et al., 2017). But, there is scarcity of data regarding the topic under study in Bangladesh and not enough data at Rangpur Medical College Hospital in Bangladesh. Therefore, this cross sectional study was performed on senior staff nurses of Bangladesh to identify knowledge and attitude regarding geriatrics health care and challenges of the nurse and to explore different type of vulnerabilities of geriatrics people in Bangladesh.

\section{Materials and Methods}

\subsection{Study design, place and period}

A cross sectional study was performed using semi structured questionnaire at Rangpur Medical College Hospital, Bangladesh, from $1^{\text {st }}$ January 2019 to $31^{\text {st }}$ December 2019.

\subsection{Study population}

The study population included senior staff nurse (both male and female) who had work experience more than six month at Rangpur Medical College Hospital.

\subsection{Sample size}

Purposive sample selection of respondent was carried out at Rangpur Medical College Hospital particular emphasis was placed on the adequacy and accuracy of the information to be collected during interviews. The reliability and validity of the information collected by semi-structured questionnaires, as well as the reliability of the entire process of data collection was tested outside the project area before the study was carried out. Sample size was calculated through following formula.

Here,

$$
\mathrm{n}=\mathrm{Z}^{2} \mathrm{pq} / \mathrm{d}^{2}
$$

$\mathrm{n}=$ desired sample size

$\mathrm{Z}=$ standard normal deviate. (in $95 \%$ confidence interval usual value is 1.96 )

$\mathrm{d}=0.05$

$\mathrm{p}=$ Probability of the study population.

$\mathrm{p}=50 \%(0.50)$, will be used as no relevant estimate was found.

$\mathrm{q}=$ Non-probability of the study population.

$\mathrm{q}=1-\mathrm{p}=(1-0.5)=0.5$

Therefore, $\mathrm{n}=\mathrm{Z}^{2} \mathrm{pq} / \mathrm{d}^{2}$

$$
=(1.96)^{2} \times 0.5 \times 0.5 /(0.05)^{2}
$$

$$
=384
$$

From the above formula the estimated sample size was 384 from Rangpur Medical College Hospital in Bangladesh. 


\subsection{Sampling method data collection technique}

Purposive sampling technique was used by face to face interview for data collection. Face to face interview was performed after taking consent from concerned authorized person.

\subsection{Research instruments}

Knowledge based questionnaire were prepared use of Nurses Knowledge of Geriatric Patients Quiz (NKGPQ) and Attitude based questionnaire were prepared use of Kogan Attitudes scale by a semi-structured questionnaire.

\subsection{Scoring of the question}

The nurse's knowledge was measured by Nurses Knowledge of Geriatric Patients Quiz (NKGPQ) which consists of 10 knowledge related questions. There were 5 response categories, among which strongly disagree, disagree and neutral option were recoded as No (0). Agree and strongly agree were recoded as Yes (1). These response categories were recoded into 3 categories. The minimum score was 1 and the maximum score was 10 . The total score was ranked as 1-5 = poor knowledge; 6-7 = average knowledge; and 8-10 = good knowledge. The respondent's attitude was measured by Kogan Attitudes scale. Kogan's attitude toward geriatric health care is a Likert-type scale and consists of 25 questions about geriatric health care. There are 5 response categories from strongly agree (5) to strongly disagree (1). The minimum score was 25 and the maximum score was 125 . The total score was ranked as 25-49= poor attitude; 50-99 = fair attitude; and 100-125 = good attitude.

\subsection{Data processing and statistical analysis}

After completion of data collection, to maintain consistency, the data were checked and edited manually and verified for any omission, error or irrelevance before tabulation. The statistical analysis was conducted using SPSS (Statistical Package for Social Science) version 24 statistical software.

\subsection{Ethical implications}

Approval was obtained from the ethical committee of National Institute of Preventive and Social Medicine (NIPSOM), under the Bangabandhu Sheikh Mujib Medical University, Dhaka, Bangladesh. Ethical clearance for the study was also obtained from the Institutional Review Board (IRB) of NIPSOM.

\section{Results}

\subsection{Socio-demographic and economic characteristics}

Among the respondents highest number was found in the age group of 21-30 years (36.46\%), followed by 31-40 years $(34.64 \%)$ and lowest $(7.03 \%)$ was in above 51 years. Participants mean $( \pm$ SD) age was $36.30( \pm 8.589)$. Among the respondents $324(84.4 \%)$ were female and next $60(15.6 \%)$ were male. Male and female ratio was $5: 27.85 .2 \%$ of the respondents were married, $12.2 \%$ were unmarried and widows were $2.6 \%$. Most of the respondents were Muslim (88.5\%). Only $10.4 \%$ of the respondents were Hindu. Educational qualifications were observed among the respondent. 207 (53.9\%) the respondents had diploma level education followed by 141 (36\%) had BSc degree, 9 (2.3\%) had MSc of 27 (7.0\%) had MPH degree (Figure 1).

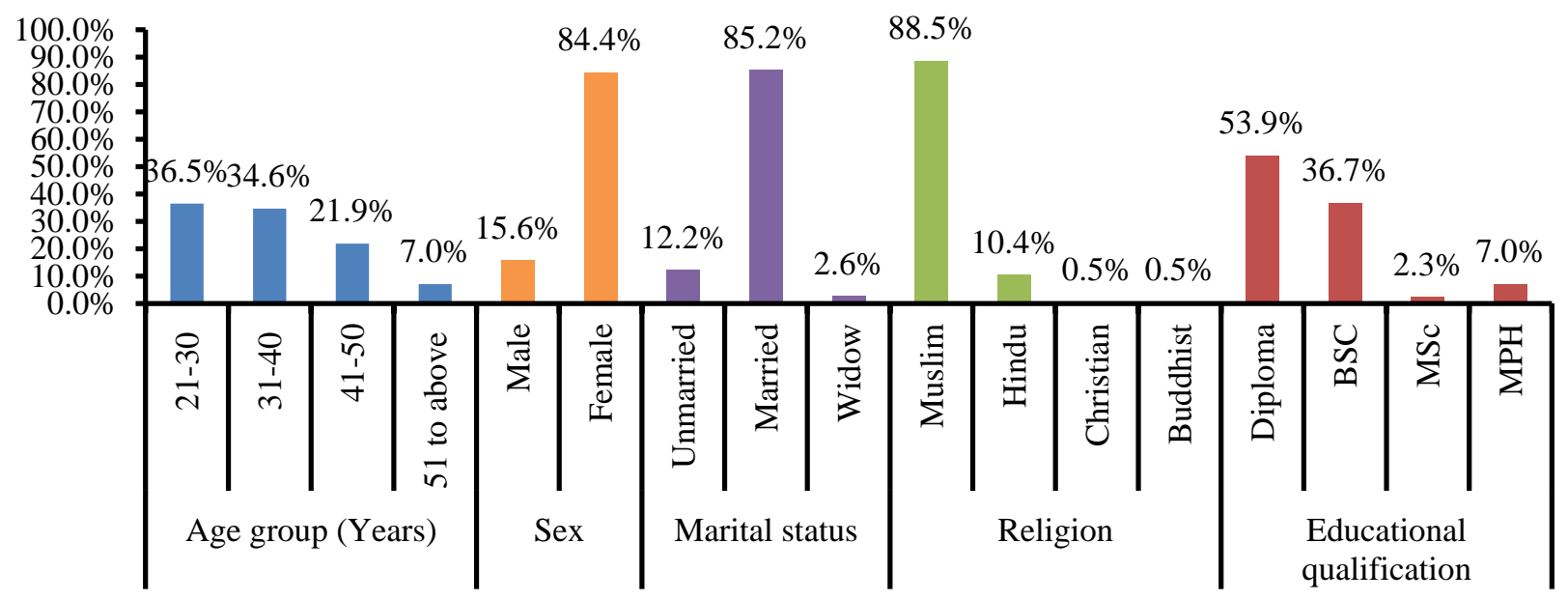

Figure 1. Distribution of different socio-demographic factors $(n=384)$. 
Income status of the respondents was categorized in five different groups. The respondent's income 1500025000 BDT was $4.2 \%$, 25001- 35000 BDT was $64.0 \%$ which was highest categories of total value. The respondent's income 35001-45000 Taka was 18.0 \%, 45001-55000 BDT was 10.2\% and income 55001 to above was $3.6 \%$ of the total number which was the lowest in frequency. The mean income was 34528.96 and Std. Deviation was 8395.626 (Figure 2).

A total of $187(48.7 \%)$ of the respondents have works experience between 1-5 years, 84 (21.9\%) of the respondents have works experience between 6-10 years, $16(4.2 \%)$ of the respondents have works experience between 11-15 years, $42(10.9 \%)$ of the respondents have works experience between 16-20 years, 30 (7.8\%) of the respondents have works experience between 21-25 years and $25(6.5 \%)$ of the respondents have works experience between 26 to above (Figure 2).

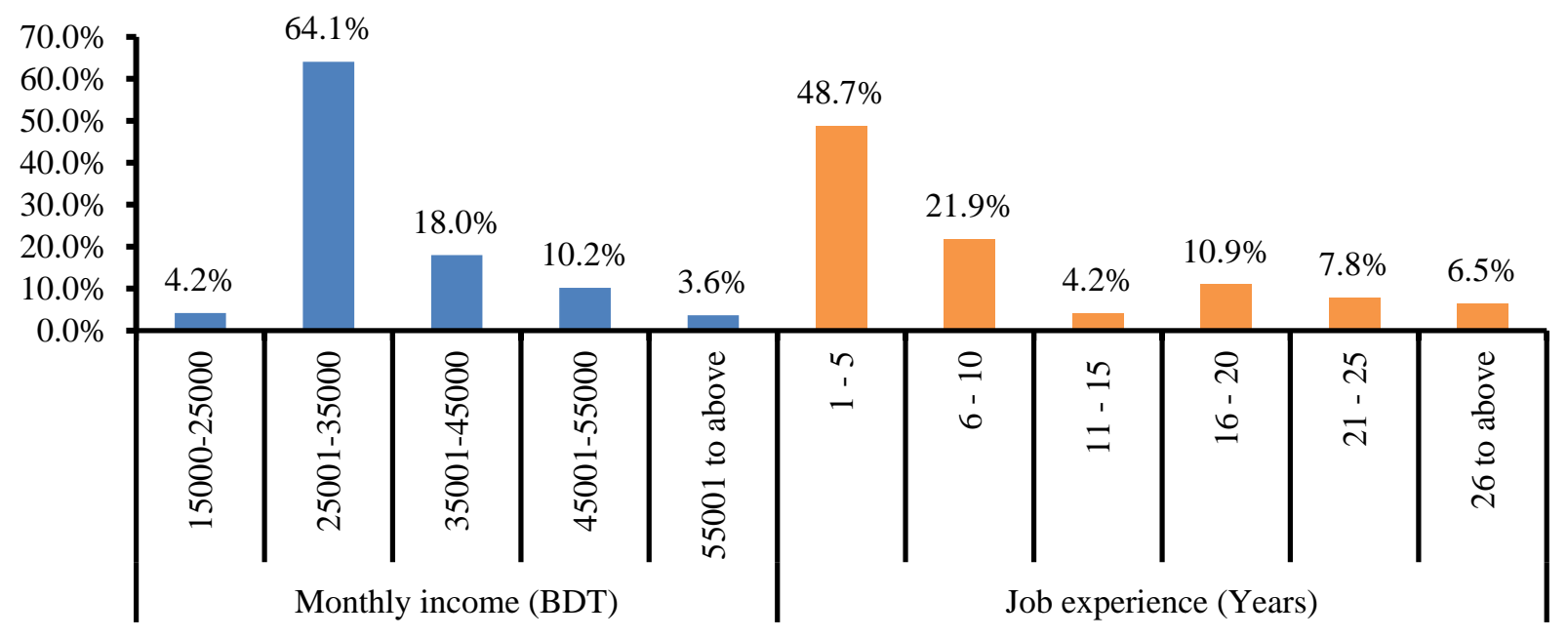

Figure 2. Distribution of monthly income and job experience $(n=384)$.

\subsection{Knowledge of senior staff nurses regarding geriatric health care according to NKGPQ scale}

According to respondents opined, $90.1 \%$ geriatric people are interesting for nurses, followed by $88.8 \%$ work with geriatric people, $88.0 \%$ challenging and stimulating work, $85.2 \%$ highly skilled job, $77.1 \%$ dissent work for nurses, $63.0 \%$ does not develop good career, $59.9 \%$ basic care, $47.4 \%$ have most probability to injury at home, $40.6 \%$ difficult to get a job and $3.1 \%$ dislike to work with geriatric people (Table 1).

Table 1. Knowledge of senior staff nurses regarding geriatric health care according to NKGPQ scale.

\begin{tabular}{lll}
\hline Items & Yes ( \%) & No ( \%) \\
\hline The geriatric people have most probability to injury at home & $182(47.4)$ & $202(52.6)$ \\
Nursing care of geriatric people is basic care does not require more skill & $230(59.9)$ & $154(40.1)$ \\
Job with geriatric people is a dissent work for nurses & $296(77.1)$ & $88(22.9)$ \\
Nursing care of geriatric people is challenging and stimulating work & $338(88.0)$ & $46(12.0)$ \\
Work with geriatric peoples have a respectfully & $341(88.8)$ & $43(11.2)$ \\
Work with geriatric people it is difficult to get a job elsewhere & $156(40.6)$ & $228(59.4)$ \\
Dislike to appeal working with geriatric people & $12(3.1)$ & $372(96.9)$ \\
Nursing care of geriatric people is a highly skilled job & $327(85.2)$ & $57(14.8)$ \\
Working with geriatric does not develop good career & $242(63.0)$ & $142(37.0)$ \\
Nursing care of geriatric people are really interesting for nurses & $346(90.1)$ & $38(9.9)$ \\
\hline
\end{tabular}

\subsection{Scores for the nurse's knowledge of geriatric people}

This study showed about one third (38.5\%) of respondents were average Knowledge, followed by 32.8\% respondents were good Knowledge and rest (28.6\%) of the respondents were Poor Knowledge to each question on the NKGPQ scale (Table 2). 
Table 2. Scores for the nurse's knowledge of geriatric people.

\begin{tabular}{ll}
\hline Nurses knowledge & Frequency (\%) \\
\hline Poor knowledge (1-5) & $110(28.6)$ \\
Average knowledge (6-7) & $148(38.5)$ \\
Good knowledge (8-10) & $126(32.8)$ \\
Total & $384(100)$ \\
\hline
\end{tabular}

\subsection{Distributions of nurse's attitudes}

There were $52.6 \%$ of the respondents agree for most geriatric people lived in housing with people their own age and $3.6 \%$ of the respondents strongly disagree for most geriatric people lived in housing with people their own age. 12 respondents $(3.1 \%)$ disagree for geriatric people lived in housing with younger people and $49.2 \%$ of the respondents strongly agree for geriatric people lived in housing with younger people. Details result of nurse attitudes regarding care of geriatric people are shown in Table 3.

Table 3. Distributions of nurses attitudes regarding care of geriatric people $(n=384)$.

\begin{tabular}{|c|c|c|c|c|c|}
\hline Attitude on geriatric people & $\begin{array}{l}\text { Strongly } \\
\text { disagree }(\%)\end{array}$ & $\begin{array}{l}\text { Disagree } \\
(\%)\end{array}$ & $\begin{array}{l}\text { Neutral } \\
(\%)\end{array}$ & $\begin{array}{l}\text { Agree } \\
(\%)\end{array}$ & $\begin{array}{l}\text { Strongly } \\
\text { agree }(\%)\end{array}$ \\
\hline $\begin{array}{l}\text { It would probably be better if most geriatric } \\
\text { people lived in residential units with people } \\
\text { their own age. }\end{array}$ & $\begin{array}{l}14 \\
(3.6)\end{array}$ & $\begin{array}{l}40 \\
(10.4)\end{array}$ & $\begin{array}{l}26 \\
(6.8)\end{array}$ & $\begin{array}{l}202 \\
(52.6)\end{array}$ & $\begin{array}{l}102 \\
(26.6)\end{array}$ \\
\hline $\begin{array}{l}\text { It would be better if most geriatric people } \\
\text { lived in housing that also housed younger } \\
\text { people }\end{array}$ & $\begin{array}{l}13 \\
(3.4)\end{array}$ & $\begin{array}{l}12 \\
(3.1)\end{array}$ & $\begin{array}{l}26 \\
(6.8)\end{array}$ & $\begin{array}{l}144 \\
(37.5)\end{array}$ & $\begin{array}{l}189 \\
(49.2)\end{array}$ \\
\hline $\begin{array}{l}\text { There is something different about most } \\
\text { people; it's hard to find out. }\end{array}$ & $\begin{array}{l}16 \\
(4.2)\end{array}$ & $\begin{array}{l}60 \\
(15.6)\end{array}$ & $\begin{array}{l}105 \\
(27.3)\end{array}$ & $\begin{array}{l}154 \\
(40.1)\end{array}$ & $\begin{array}{l}49 \\
(12.8)\end{array}$ \\
\hline $\begin{array}{l}\text { Most geriatric people are really no different } \\
\text { from anybody else and easy to understand } \\
\text { as younger people. }\end{array}$ & $\begin{array}{l}15 \\
(3.9)\end{array}$ & $\begin{array}{l}48 \\
(12.5)\end{array}$ & $\begin{array}{l}129 \\
(33.6)\end{array}$ & $\begin{array}{l}136 \\
(35.4)\end{array}$ & $\begin{array}{l}56 \\
(14.6)\end{array}$ \\
\hline $\begin{array}{l}\text { Most geriatric people get set in their ways } \\
\text { and are unable to change. }\end{array}$ & $\begin{array}{l}34 \\
(8.9)\end{array}$ & $\begin{array}{l}72 \\
(18.8)\end{array}$ & $\begin{array}{l}32 \\
(8.3)\end{array}$ & $\begin{array}{l}184 \\
(47.9)\end{array}$ & $\begin{array}{l}62 \\
(16.1)\end{array}$ \\
\hline People grown wiser with old age & $\begin{array}{l}18 \\
(4.7)\end{array}$ & $\begin{array}{l}41 \\
(10.7)\end{array}$ & $\begin{array}{l}55 \\
(14.3)\end{array}$ & $\begin{array}{l}207 \\
(53.9)\end{array}$ & $\begin{array}{l}63 \\
(16.4)\end{array}$ \\
\hline
\end{tabular}

\subsection{Nurses attitude towards social facts}

A total of 185 (48.2\%) respondents agree for geriatric people capable of new adjustments when the situation demands and $4.9 \%$ of the respondents strongly disagree for geriatric people capable of new adjustments when the situation demands. There were 59.6\% of the respondents agree for geriatric people bore others by talking and $2.6 \%$ of the respondents strongly disagree for geriatric people bore others by talking. Details result of nurse attitudes towards social facts are shown in Table 4.

Table 4. Nurses attitude towards social facts $(n=384)$.

\begin{tabular}{|c|c|c|c|c|c|}
\hline Items & $\begin{array}{l}\text { Strongly } \\
\text { disagree }(\%)\end{array}$ & $\begin{array}{l}\text { Disagree } \\
(\%)\end{array}$ & $\begin{array}{l}\text { Neutral } \\
(\%)\end{array}$ & $\begin{array}{l}\text { Agree } \\
(\%)\end{array}$ & $\begin{array}{l}\text { Strongly } \\
\text { agree }(\%)\end{array}$ \\
\hline $\begin{array}{l}\text { Most elderly people would prefer to quit work } \\
\text { as soon as pensions or their children can } \\
\text { support them. }\end{array}$ & $\begin{array}{l}19 \\
(4.9)\end{array}$ & $\begin{array}{l}85 \\
(22.1)\end{array}$ & $\begin{array}{l}68 \\
(17.7)\end{array}$ & $\begin{array}{l}185 \\
(48.2)\end{array}$ & $\begin{array}{l}27 \\
(7.0)\end{array}$ \\
\hline $\begin{array}{l}\text { Most geriatric people bore others by talking } \\
\text { about the good old days. }\end{array}$ & $\begin{array}{l}10 \\
(2.6)\end{array}$ & $\begin{array}{l}15 \\
(3.9)\end{array}$ & $\begin{array}{l}26 \\
(6.8)\end{array}$ & $\begin{array}{l}229 \\
(59.6)\end{array}$ & $\begin{array}{l}104 \\
(27.1)\end{array}$ \\
\hline $\begin{array}{l}\text { Most geriatric people's past experiences are } \\
\text { interesting. }\end{array}$ & $\begin{array}{l}8 \\
(2.1)\end{array}$ & $\begin{array}{l}25 \\
(6.5)\end{array}$ & $\begin{array}{l}27 \\
(7.0)\end{array}$ & $\begin{array}{l}165 \\
(43.0)\end{array}$ & $\begin{array}{l}159 \\
(41.4)\end{array}$ \\
\hline $\begin{array}{l}\text { Most geriatric people respect others privacy } \\
\text { and give advice only when asked. }\end{array}$ & $\begin{array}{l}5 \\
(1.3)\end{array}$ & $\begin{array}{l}11 \\
(2.9)\end{array}$ & $\begin{array}{l}157 \\
(40.9)\end{array}$ & $\begin{array}{l}157 \\
(40.9)\end{array}$ & $\begin{array}{l}54 \\
(14.1)\end{array}$ \\
\hline $\begin{array}{l}\text { Most geriatric people are constantly } \\
\text { complaining about the young generation's } \\
\text { behavior. }\end{array}$ & $\begin{array}{l}24 \\
(6.3)\end{array}$ & $\begin{array}{l}37 \\
(9.6)\end{array}$ & $\begin{array}{l}35 \\
(9.1)\end{array}$ & $\begin{array}{l}223 \\
(58.1)\end{array}$ & $\begin{array}{l}65 \\
(16.9)\end{array}$ \\
\hline
\end{tabular}




\subsection{Nurses attitude towards skillness}

There were $47.9 \%$ of the respondents disagree for geriatric people maintain a nice neighborhood and $4.2 \%$ of the respondents strongly agree for geriatric people maintain a nice neighborhood. There were $32.8 \%$ of the respondents agree for nice neighborhood one that a number of old people living and $9.6 \%$ of the respondents strongly disagree for nice neighborhood one that a number of old people living. Details are shown in Table 5.

Table 5. Nurses attitude towards skillness $(\mathbf{n}=\mathbf{3 8 4})$.

\begin{tabular}{|c|c|c|c|c|c|}
\hline Items & $\begin{array}{l}\text { Strongly } \\
\text { disagree } \\
(\%)\end{array}$ & $\begin{array}{l}\text { Disagree } \\
(\%)\end{array}$ & $\begin{array}{l}\text { Neutral } \\
(\%)\end{array}$ & $\begin{array}{l}\text { Agree } \\
(\%)\end{array}$ & $\begin{array}{l}\text { Strongly } \\
\text { agree }(\%)\end{array}$ \\
\hline $\begin{array}{l}\text { In order to maintain a nice neighborhood, it } \\
\text { would be best if geriatric people did not live } \\
\text { in it }\end{array}$ & $\begin{array}{l}94 \\
(24.5)\end{array}$ & $\begin{array}{l}184 \\
(47.9)\end{array}$ & $\begin{array}{l}51 \\
(13.3)\end{array}$ & $\begin{array}{l}39 \\
(10.2)\end{array}$ & $\begin{array}{l}16 \\
(4.2)\end{array}$ \\
\hline $\begin{array}{l}\text { A nice neighborhood is one that has a number } \\
\text { of old people living in it. }\end{array}$ & $\begin{array}{l}37 \\
(9.6)\end{array}$ & $\begin{array}{l}60 \\
(15.6)\end{array}$ & $\begin{array}{l}132 \\
(34.4)\end{array}$ & $\begin{array}{l}126 \\
(32.8)\end{array}$ & $\begin{array}{l}29 \\
(7.6)\end{array}$ \\
\hline $\begin{array}{l}\text { Most geriatric people are very different from } \\
\text { one another. }\end{array}$ & $\begin{array}{l}16 \\
(4.2)\end{array}$ & $\begin{array}{l}61 \\
(15.9)\end{array}$ & $\begin{array}{l}89 \\
(23.2)\end{array}$ & $\begin{array}{l}165 \\
(43.0)\end{array}$ & $\begin{array}{l}53 \\
(13.8)\end{array}$ \\
\hline Most geriatric people are very easy to be with. & $\begin{array}{l}15 \\
(3.9)\end{array}$ & $\begin{array}{l}208 \\
(54.2)\end{array}$ & $\begin{array}{l}29 \\
(7.6)\end{array}$ & $\begin{array}{l}105 \\
(27.3)\end{array}$ & $\begin{array}{l}27 \\
(7.0)\end{array}$ \\
\hline
\end{tabular}

\subsection{Factors influencing the attitude of nurses in towards care of the geriatric people}

There were $93.8 \%$ geriatric people effective care requires special training and $6.3 \%$ geriatric people effective care requires no special training. There were $97.7 \%$ hospitals needs special geriatric wards for effective care of the geriatric people and 2.3\% hospitals needs no special geriatric wards for effective care of the geriatric people. Details are shown in Table 6.

Table 6. Factors influencing the attitude of nurses in towards care of the geriatric people $(n=384)$.

\begin{tabular}{lll}
\hline Items & $\begin{array}{l}\text { Yes } \\
{[\text { No. (\%)] }}\end{array}$ & $\begin{array}{l}\text { No } \\
{[\text { No. (\%)] }}\end{array}$ \\
\hline $\begin{array}{l}\text { Effective care of the elderly requires special training } \\
\text { Hospitals should have special wards i.e geriatric wards for effective care of the } \\
\text { elderly. }\end{array}$ & $360(93.8)$ & $24(6.3)$ \\
Mental status of the geriatric patients affects their care and decision making & $333(96.7)$ & $9(2.3)$ \\
Geriatric patients exhibit different behaviors which affect their care & $355(92.4)$ & $51(13.3)$ \\
It is difficult to persuade and convince reluctant patient about their care in the hospital. & $364(94.8)$ & $20(7.6)$ \\
Some geriatric people are abandoned due to lack of family support. & $381(99.2)$ & $3(0.8)$ \\
\hline
\end{tabular}

\subsection{Statistical relationship of different factors}

According to Kogan's Geriatric People's Scale (KGPS) the attitude of $36.2 \%$ respondents have negative attitudes and $63.8 \%$ of the respondents have positive attitudes. Chi square test was done to know the relationship among jobs experience, knowledge and attitude of the respondents. The association between the jobs experience and knowledge of the respondents was statistically significant among the respondents $\left(\lambda^{2}=15.04, p<0.04\right)$.

The relationship between the jobs experience and attitude of the respondents was statistically provisionally significant among them $\left(\lambda^{2}=26.193, \mathrm{p}<0.05\right)$. It means that weak evidence against the job experience. Pearson Correlation was performed to know the statistical relationship between knowledge and attitude, a significant correlation between knowledge and attitude regarding care of geriatric people $(r=0.1)$ was found.

\section{Discussion}

The present study was performed to assess the knowledge and attitude of senior staff nurses regarding geriatrics health care and the factors influencing the attitude of nurses in a tertiary public hospital. The theory of planned behavior (Fishbein and Ajzen, 1975) was used in this study as a conceptual framework because it offers a constructive and plausible way to identify intentions related to attitude, willingness and clinical experiences among nursing care toward working with geriatric people. Regarding the age of the respondent's majority $36.5 \%$ was in age group of $21-30$ years. Similar study was found Faronbi et al. (2017). However, places such as China and India will have slightly more than 20 years to make the same adaptation (Barikdar et al., 2016). 
The educational qualification of our study also stated with Oulton and Hickey (2009); Berland, 2014. Due to the religious majority of a country highest number of Muslim found in our study, it also supported by Nolan et al. (2002) and Baumbusch et al. (2016) who said about the religious majority in certain country.

Nolan et al. (2002) reported in the UK that large numbers of nurse had worked with geriatric people previously and many for several (often 10+) years. In contrast, in this study the results showed that $48.7 \%$ have works experience between $1-5$ years, $21.9 \%$ of the respondents have works experience between 6-10 years and only $7.8 \%$ of the respondents have works experience between 21-25 years. In this light, it appears that clinical past experiences with older people can play a major role in acceptance or non-acceptance of working with older people as a career option among nursing students (Yun-E et al., 2013).

There were $35.4 \%$ of the respondents agree for geriatric people care requires skill nurse and $9.4 \%$ of the respondents strongly agree for geriatric people care requires skill nurse. According to Faronbi et al. (2017), 70\% believed that basic nursing skills are inadequate in elder care. The situation of the elderly is dismal where more than $50 \%$ of the elderly are widowed or single (Abedin, 1996) $0.63 \%$ are jobless and $14-15 \%$ engaged in agricultural works and daily labor. This compares badly with that of Tehran where $85 \%$ elderly are unofficially employed (Uddin et al., 2010). Bangladesh introduced Program Implementation Plan for protecting old age health and ensures health care. This program aims to provide efficient and sustainable health service delivery and management system with skilled and special emphasis on the development of a sustained health system and improved and responsive efficient human resources (Barikdar et al., 2016).

Moreover, research shows that children of older parents in Bangladesh live in cities for various purposes. Again, the older people fill comfortable to live in the rural settings and sometimes children are leaving their older parents to live in the city (Rahman, 1999). $44.3 \%$ people live in poverty and in order to maintain their living expenses as well as family needs; the elderly people get involved in beggary (Rahman, 2000). Similarly, Meredith (1995) points out that due to failures to establish good quality care for older people in institutional environments, many older people prefer to stay in their own homes. Exposing nurse to this type of situation early in their training was seen to negatively affect their perceptions of work with older people. Out study found 93.8\% geriatric people effective care requires special training and $6.3 \%$ geriatric people effective care requires no special training. Moreover, the healthcare provided for the elderly people has been severely threatened by the negative stereotypic attitudes and misconceptions by nurses with $63 \%$ of elders expressing an unmet health need (King et al., 2013).

The consistency and size of the positive relationships between attitude and work preferences toward older people among nursing students in this study gives some support for the usefulness of Fishbein and Ajzen's model relating attitudes and behavioral intentions. The current study's findings support Alamri et al. (2017), who reported that nurses were reluctant to work with older people at the end of their training because they encountered poor standards of care and a lack of motivation and expressed the feeling that gerontological nursing was stigmatized.

Similarly, Kwon et al. (2013) pointed out that community-based provision for the care of older people has expanded and offers new routes for the specialist training of nurses in community settings. This change will increase the demand for more skilful and experienced nurses in specialized fields such as community health nursing for older people. Similarly, Eloranta et al. (2014) suggest that to improve the nurses' kills and knowledge with regard to the care of older people, schools of nursing must emphasize community gerontology nursing.

Our study revealed that $36.2 \%$ of the respondents have negative attitudes and $63.8 \%$ of the respondents have positive attitudes. Similarly, in this study, the quantitative data alone were not sufficient to explore and understand the meaning of positive attitudes among nursing student toward older people. Murray (2002) has this to say about societal attitudes towards the aged.

The findings of this study support those of Oyetunde et al. (2013) and Arani et al. (2017), who stated that knowledge about older adults, did not increase significantly during the integrated curriculum, as clearly shown in this study. In fact, this lack of knowledge about ageing among nursing students is not only a problem in Saudi Arabia but also worldwide (Zakari, 2005).

The association between the jobs experience and attitude of the respondents was statistically provisionally significant among them $\left(\lambda^{2}=26.193, \mathrm{p}>0.05\right)$. It means that weak evidence against the job experience. According to Faronbi et al. (2017) majority (66.1\%) of the respondents have positive perception of the older adults; $71.7 \%$ respondents have positive attitude towards the older adults and $60 \%$ of the respondents have good knowledge about the care of the older adults. Level of significance was set at $p<$ to 0.05 , two variables tested were not significant. The association between the jobs experience and knowledge of the respondents was statistically significant among them $\left(\lambda^{2}=15.04, \mathrm{p}<0.04\right)$. It means that strong evidence against the null 
hypothesis in favor of the alternative. According to Artishedar et al. (2015) a positive relationship was found between knowledge about aging and life satisfaction.

\section{Conclusions}

This study reveal that majority of nurses had average knowledge regarding care of elder patient, Job experience in nursing profession and attitude, and knowledge had significant association toward care of elder patient, similarly significant number of nurses had negative attitude towards care of elder patient. Therefore, conduct special trainings for nurses to enhance their knowledge and attitude on the care of elder patient. In addition to this develop and implement geriatric care training formal curriculum, higher level of administrators including ministry of health should develop and implement standard guideline in order to improve the nursing care of elder patients.

\section{Conflict of interest}

None to declare.

\section{References}

Abedin S, 1996. Population aging in Bangladesh. Issues and Perspectives, Summary of the Country Paper, ESCP, Asian Popultion Studies Series, 1996, No. 145.

Alamri BH and DX Lily, 2017. Health professionals' knowledge and attitudes toward older people in primary care in Saudi Arabia." Saudi Med. J., 38: 229-236.

Anil JP, B Joy, K Malini, V Kavita and P Perushottam, 2006. Morbidity pattern among the elderly population in the rural area of Tamil Nadu, India. Turk. J. Med. Sci., 36: 45-50.

Arani MM, S Aazami, M Azami and M Borji, 2017. Assessing attitudes toward elderly among nurses working in the city of Ilam, Int. J. Nurs. Sci., 4: 311-313.

Argaw Z, S Tamiru, Y Ayalew and T Habte, 2018. Knowledge and attitude towards care of elder patients and associated factors among nurses working in government hospitals in Addis Ababa, Ethiopia. Int. J. Eng. Res., 9: 1979-1992.

Artishedar A, JM Agha and Z Ghahremani, 2015. Attitudes toward Elderly among Nurses working in MedicalSurgical Wards in Zanjan hospitals, 2012. Preventive Care in Nursing and Midwifery Journal, 15: 81-90,

Barikdar A, T Ahmed and SP Lasker, 2016. The situation of the elderly in Bangladesh. Bangladesh Journal of Bioethics, 7: 27-36.

Baumbusch J, M Leblanc, M Shaw and M Kjorven, 2016. Factors influencing nurses' readiness to care for hospitalized older people. "Int. J. Older People Nurs., 11: 149-59.

Berland A, 2014. Advancing Nurse Education in Bangladesh. https://www.researchgate.net/publication/313715175.

Celik SS, S Kapucu, Z Tuna and Y Akkus, 2010. Views and attitudes of nursing students towards ageing and older patients. Aust. J. Adv. Nurs., 27: 24.

Doherty M, EA Mitchell and S O'Neill, 2011. Attitudes of healthcare workers towards older people in a rural population: A survey using the Kogan Scale. Nursing Research and Practice, 14: 1-7.

Eloranta S, S Arve, H Isoaho, I Aro, L Kalam-Salminen and P Routasalod, 2014. Finnish nurses' perceptions of care of older patients. Int. J. Nurs. Pract., 20: 204-211.

Eymard AS and DH Douglas, 2012. Ageism among health care providers and interventions to improve their attitudes toward older adults. J. Gerontol. Nurs., 38: 26-35.

Faronbi JO, O Adebowalea, GO Faronbia, OO Musaa and SJ Ayamolowoa, 2017. Perception knowledge and attitude of nursing students towards the care of older patients. Int. J. Africa Nurs. Sci., 7: 37-42.

Fishbein M and I Ajzen, 1975. Belief, attitude, intention, and behaviour: an introduction to theory and research. Reading, MA, Addison-Wesley Publishing Company.

Kabir M, M Haque and H Chaklader, 2005. Mainstreaming ageing in health: Will it be possible. Paper presented in the International conference on mainstreaming ageing in health system and rural development, Dhaka, November, 2005.

Kaur S, A Kumar, B Kaur, B Rani, S Ghai and M Singla, 2014. Knowledge and Attitude Regarding Care of Elderly Among Nursing Students: An Indian Perspective. J. Nurs. Care 3: 161.

King BJ, TJ Roberts and BJ Bowers, 2013. Nursing student attitudes toward and preferences for working with older adults. Gerontol. Geriatr. Educ., 34 (3), 272-291.

Kwon Y, HY Lee and SS Hwang, 2013. A study on the knowledge, attitude and nursing practice of the nursestowards the elderly in geriatric hospitals. J. Korea Acad. Industr. Coop. Soc., 14: 5785-91. 
Meredith B, 1995. The Community Care Handbook. The reformed system explained (2nd ed.) London, Age Concern.

Murray K, 2002. Poor quality of elderly care deterring students. Nursing Standard, 16: 7.

Nolan M, J Brown, S Davies and J Keady, 2002. Longitudinal study of the effectiveness of educational preparation to meet the needs of older people and their carers: the advancing gerontological education in nursing (the AGEIN project). English National Board for Nursing, Midwifery and Health Visiting.

Oulton J and B Hickey, 2009. Review of the nursing crisis in Bangladesh, India, Nepal and Pakistan. London, UK: Department for International Development.

Oyetunde MO., OO Olufisayo and YO Lucia, 2013. Nurses' attitude towards the care of the elderly: implications for gerontological nursing training. J. Nurs. Educ. Pract., 3: 150-158.

Rahman A, 2000. Beggary on aging: an analysis (Bangoli). Dhaka University Patrica, Dhaka, Vol. 66, pp: 89.

Rahman H, 1999. International year of the older persons and the cases of Bangladesh. Bangladesh J. Geriatrics, 36: 144-144.

Tavares JP, AL Silva, P Sá-Couto, M Boltz and E Capezuti, 2017. Nurse perception of care of hospitalized older adults a comparative study between northern and central regions of Portugal. Rev. Latino-Am. Enfermagem., 25: e2757.

Uddin MJ, MN Islam, MJ Alam and GU Baher, 2010. Socio-Eonomic status of elderly of Bangladesh: a statistical analysis. J. Appl. Sci., 10: 3060-3067.

Yun-E L, IJ Norman and E Alison E, 2013. Nurses attitudes towards older people: A systematic review. Int. J. Nurs., 50: 1271-1282

Zakari N, 2005. Attitudes toward the elderly and knowledge of aging as correlates to the willingness and intention to work with the elderly among Saudi nursing students. Ph. Dthesis, George Mason University, Virginia. 